\title{
Policy, Institutions and Non-Oil Exports: Evidence from Nigeria
}

\author{
Martins Iyoboyi $^{1} \&$ Abdelrasaq Na-Allah ${ }^{1}$ \\ ${ }^{1}$ Department of Economics and Development Studies, Federal University Dutsinma, Nigeria \\ Correspondence: Martins Iyoboyi, Department of Economics and Development Studies, Federal University \\ Dutsinma, Nigeria. Tel: 234-803-795-4183. E-mail: miyoboyi@ fudutsinma.edu.ng; miyoboyi@ gmail.com
}

Received: June 11, 2015

doi:10.5539/ijef.v7n11p10
Accepted: September 6, 2015

Online Published: October 25, 2015

\begin{abstract}
In this paper, the impact of policy and institutions on non-oil exports in Nigeria is investigated, using data from secondary sources for the period 1961-2012, and implemented through the autoregressive distributed lag framework. Non-oil exports were found to have a long-run equilibrium relationship with policy and institutional variables. Money supply and exchange rate were found to be positively associated with and statistically significant determinants of non-oil exports in the long and short run. Fiscal deficit, interest rate, 'constraints on the executive' and openness were found to be inversely related to non-oil exports in both the short and long run. While inflation was found to be negatively related to non-oil exports in the short run, it is the reverse in the long run. An enhanced political institutional framework is required, that is attuned to growth in the non-oil sector of the economy, as a mechanism for improving the country's non-oil exports.
\end{abstract}

Keywords: Autoregressive distributed lag model, fiscal policy, institutions, monetary policy, non-oil exports

\section{Introduction}

The primacy of exports is aptly encapsulated in the export-led growth hypothesis which considers increased export earnings as an "engine of economic growth" due to its capacity to induce employment, improve productivity, reduce prices, and improve a country's reserves (McCombie \& Thirlwall, 1994; Goldstein \& Pevehouse, 2008). Due to the high proportions of exports of developing countries comprising natural resources or mining-industry goods, developing the non-oil sector becomes a sure way of combating undesirable consequences such as the Dutch Disease while warranting policies targeted at higher export performance (Sorsa, 1999).

For Nigeria, a country rich in mineral resources, a booming oil resource sector has tended to draw capital and labour away from the country's agricultural and manufacturing sectors, leading over time to sharp declines in non-oil exports, with the attendant consequences of higher price levels, worsening balance of payments, unemployment and falling living standards.

The patterns of Nigeria's trade flows between 1980 and 2012 are shown in Figures 1 and 2.

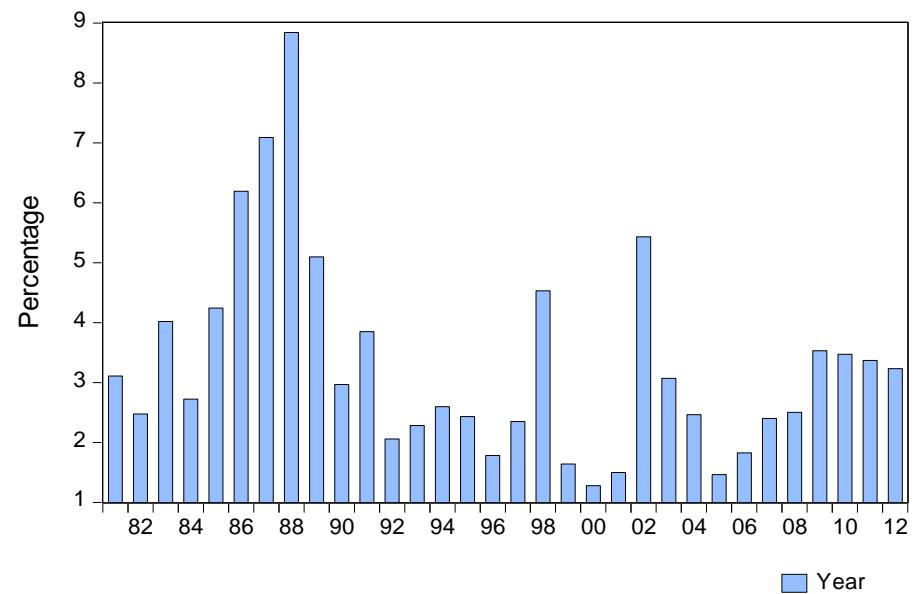

Figure 1. Non-oil exports as a percentage of total exports (1981-2012) 


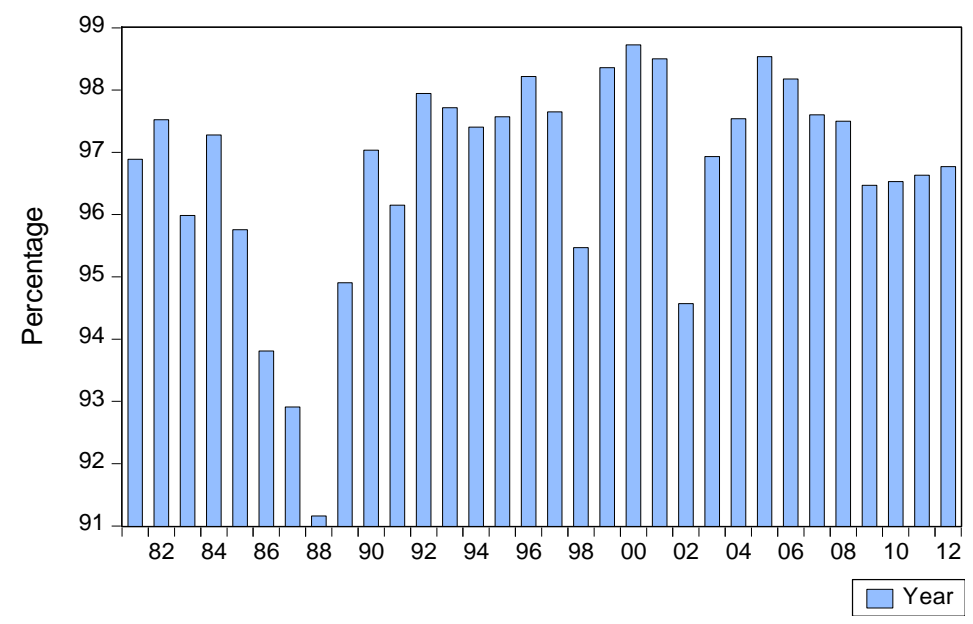

Figure 2. Oil exports as a percentage of total exports (1981-2012)

Source: Authors' computations from Central Bank of Nigeria data.

From Figure 1, it can be observed that the volume of non-oil exports as a proportion of total exports did not exceed 9\% between 1980 and 2012. On the other hand, the share of oil exports in total exports has been fairly stable and on the high side throughout the period as shown in Figure 2. Consequently, non-oil exports for the Nigerian economy cannot be said to have improved remarkably over the last three decades.

A different understanding about development has arisen in recent times, due to the rise of institutional analysis. Specifically, emphasis is shifting to deeper understanding of the capacity of countries to develop and implement policies around local institutions, as doing this is a surer mechanism for success. What the new intuitions suggest is that the failure of macroeconomic policies may in part be explained by poor understanding of the nature of institutions in less developed countries, spiced by the low capacity for implementing reform. This is not without solid foundation. For example, from the early 1980s to the 2000s, macroeconomic volatility along with discouraging macroeconomic outcomes pervaded the global economy, with low income and developing countries worst hit. In Sub-Saharan Africa, problems ranging from debt overhang, high rate of inflation, to high unemployment and poverty prevailed. Part of the responses in the sub-region was a shift from plan to deregulation and liberalization, both of which led to the adoption of a matrix of austerity measures.

What can be surmised from new thinking in empirical research on development is that economic performance may reflect not only the impact of macroeconomic policies, but that there may be deep underlying institutional causes which result in the particular policies. In the case of Nigeria, it is plausible to conclude that several policy measures have done very little to improve macroeconomic performance in terms of non-oil exports, employment, lower prices and equitable income distribution. In specific terms, measures such as the adoption of the Structural Adjustment Programmes (SAP) in the mid 1980s and the removal of the overvalued exchange rate in 2008 and the subsequent devaluation of the country's currency had no appreciable impact on economic performance due probably to institutional causes.

Early insights into the role that institutions can play in economic performance date back to Adam Smith who postulated that without a certain degree of confidence in the justice of government, little development can take place in commerce and manufacturing, implying that the degree of economic performance is linked to the rule of law. He also asserts that the differences in growth rates via differences in investment rates were a function of the rule of law and property rights. Thus, the institutional framework has been identified in the literature as an important source of growth, and although its importance had been acknowledged after Smith (e.g. Lewis, 1955; Ayres, 1962), it was only recently that it was subjected to more consistent empirical examination (e.g. Knack \& Keefer, 1995; Mauro, 1995; Hall \& Jones, 1999; Rodrik, 2000; Acemoglu et al., 2002).

An empirical examination of the impact of institutional and policy framework on Nigeria's non-oil exports is important for a variety of reasons. In 2014, Nigeria became Africa's largest economy and the $26^{\text {th }}$ largest in the World. The country is Africa's highest oil exporter, and the world's tenth largest oil producing country. The country has realized over US\$ 600 billion in oil revenues since 1960, a figure greater than the resources used by the Marshall Plan in rebuilding post World War II Europe.Nigeria's economy is heavily dependent on natural 
resources: oil and gas constitutes $98 \%$ of total exports, $80 \%$ of government revenues and around $20 \%$ of gross domestic product (Central Bank of Nigeria, 2010). Despite enormous potentials on the economic front, Nigeria has largely failed to live up to the projections following the first oil boom era of the 1970s, and thus its macroeconomic responsibilities of high employment, low inflation, positive external balance and improved living standards have been elusive. In all of this, the ambit of well functioning institutions and their accompanying structures and mechanisms are often left out in the analysis of the country's macroeconomic performance. The persistence of high distortions and underperformance in several sectors of the economy can be x-rayed or analyzed from outside the ambit of policy making to one in which due cognizance is taken of the institutional setting and environment.

In the era of structural reform, policy was geared towards driving the economy by the private sector, removal of exchange rate overvaluation and its subsequent determination by market forces, tariff reforms, deregulation of the economy, all of which were aimed at removing government distortions, and "getting the prices right". Although there were occasional marginal improvements in GDP figures, the country on the whole is still faced with daunting economic and political challenges. Inefficiencies and waste, corruption, high unemployment, violent conflicts and poor living standards with all their attendant consequences are commonplace. Where growth improved, it was not inclusive, as it neither reduced poverty nor enhanced development. Overtime, the country's human development indicators have remained weak, with significant variations among states and geo-political zones in the country. From about 27 percent in 1980 to 65.6 percent in 1996, 54.4 percent in 2004 and 69 percent in 2010, relative poverty incidence has worsened (World Bank, 2012). Nigeria was among the countries with the highest inequality levels in the world, as indicated by the Gini coefficient which saw an upward rise from 0.429 in 2004 to 0.447 in 2010.

An examination of the Worldwide Governance Indicators which use aggregate indicators of six broad dimensions of governance [estimate of governance ranges from approximately -2.5 (weak) to 2.5 (strong) governance performance], indicates that Nigeria's economic governance institutions are weak, as encapsulated in Table 1.

Table 1. Performance of Nigeria's economic governance institutions

\begin{tabular}{|c|c|c|c|}
\hline \multirow[t]{2}{*}{ Governance Indicator } & \multicolumn{2}{|c|}{ Performance Scores } & \multirow[t]{2}{*}{ Conclusion } \\
\hline & 1996 & 2012 & \\
\hline Voice and Accountability & -1.66 & -0.73 & Marginal improvement \\
\hline Political Stability \& Absence of Violence/Terrorism & -1.17 & -2.05 & Worsened \\
\hline Government Effectiveness & -0.98 & -1.00 & Worsened \\
\hline Regulatory Quality & -0.82 & -0.72 & Poor \\
\hline Rule of Law & -1.26 & -1.18 & Marginal improvement \\
\hline Control of Corruption & -1.15 & -1.13 & Poor \\
\hline
\end{tabular}

Source: Compiled by authors from World Bank data.

From Table 1, it can be seen that in all aspects of governance indicators, Nigeria's performance was below average between the periods. Worse still is that the independence and professionalism of the public sector in the country's has been progressively on the decline. Ranked as the most corrupt nation in 1995, 1996 and 1997, the country has been among the 10 most corrupt countries in the world for close to two decades (Transparency International, various years). Coupled with this is that the civil society is weak and faces a Herculean task in bringing public pressure to bear on institutional changes required for good economic governance and effective delivery on macroeconomic objectives.

Many empirical investigations on factors impacting non-oil exports have tended to neglect the role of the institutional environment, with a general focus on real exchange rate and associated factors. In a study by Bernardina (2004) on the impact of real exchange rate, real non-oil GDP, and the world income on non-oil export, a robust and negative long run relationship was found between the real exchange rate and non-oil exports, while the world income and real non-oil GDP have positive and negative effects on non-oil exports respectively. Masoud and Rastegari (2008) found that Iran's non-oil exports respond positively to increased population, per capita income and consumer price index while inversely related to real exchange rate appreciation.

Majority of the studies on Nigeria are invariably on exchange rate impact on non-oil exports (Oyejide, 1986; Ogun, 1998; Abolagba et al., 2010). Overall, evidence points to a negative impact on exports of real exchange 
rate appreciation. Given the importance that macroeconomic policies play in international transactions, it needs to be asserted that they in themselves will not translate to improved non-oil performance, especially in an environment of weak and inert institutions. Surprisingly, empirical attempts linking non-oil export performance to institutions are lacking in the literature.

From the foregoing, the paper explores the dynamic relationship between non-oil growth and institutional and policy factors on the Nigerian economy. Empirical studies on the role of institutions on the macroeconomic performance from the point of view of non-oil exports on an oil-dependent economy such as Nigerian are visibly absent. The paper contributes to existing empirical literature by investigating the influence of institutions and policy on non-oil exports. Following the introduction, the rest of the paper is structured as follows. Methodology is covered in Section 2. The empirical results and discussions are presented in Section 3. The paper is concluded in Section 4.

\section{Method}

\subsection{Sources and Description of Data}

Annual data for the period 1961 to 2012 was employed in the study. The data was obtained from various issues of the Statistical Bulletin of the Central Bank of Nigeria and the World Bank. Fiscal deficit was taken as a measure of fiscal policy; broad money supply and interest rate were used to capture monetary policy, while 'constraints on the executive' was utilized as a proxy for institutions. The variables were transformed into logarithms in order to capture nonlinear properties and to correct for heteroskedasticity; fiscal deficit is expressed in growth rates to avoid the problems associated with logarithms of non-positive numbers.

On the proxy of institutions employed, a version of institutional variable called 'Constraints on the executive' is adopted. This measure has been previously employed in empirical analysis (e.g. Acemoglu et al., 2003; Fatas \& Mihov, 2006). The calculation is implemented as follows:

\section{Constraints $=$ Federal + Legislature + Judiciary + Upper Chamber}

Each of the right hand dummy variables takes the value of 1 if the specific institution existed in a particular time and 0 if otherwise. Consequently, the constraint 'Federal' equals 1 if the country has a federal structure, implying the share of political power between the central and state governments. Legislature is equal to 1 where the national assembly is freely elected and independent of the executive. Judiciary takes the value of 1 where the judiciary is separate from the executive arm of government. Upper chamber takes the value of 1 if the country has a bi-cameral legislature and 0 otherwise. The choice of this variable is informed by its measurement of how much freedom the executive has in changing policy stance. The variable thus captures potential veto points on the decisions made by the executive arm of government and the value taken at any time by the particular variable depends on the number of checks originating from the right hand side of the equation. The role that constraints play in the determination of economic and political outcomes has been extensively investigated in the literature of political economy (Tsebelis, 2002).

\subsection{Model Specification and Procedure Employed in Estimation}

In the empirical analysis of the long-run relationships between non-oil exports, institutions and policy, the following procedure was followed. In the first place, the order of integration of the variables employed was examined. Second, the presence or otherwise of a long-run equilibrium relationship was investigated, using the bounds testing approach to cointegration proposed by Pesaran et al. (2001), which has certain econometric advantages over traditional approaches such as those of the two-step procedure of Engle and Granger (1987), the Full Information Maximum Likelihood-based approach of Johansen (1988, 1996), Phillips and Hansen (1990) and Johansen and Juselius (1990), the major defect being that they are inadequate for small samples, and thus have unsatisfactory small sample properties. For the Pesaran et al. (2001) methodology, it is applicable irrespective of whether the underlying regressors are purely $\mathrm{I}(0)$, purely $\mathrm{I}(1)$ or fractionally cointegrated. Moreover, its statistical properties in small samples are robust when subjected to small sample sizes. Importantly, the long and short run parameters of a model can be estimated.

The specification of the non-oil export growth equation for Nigeria, using the ARDL model is presented in a log-linear form as follows:

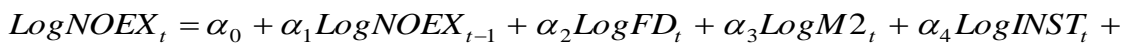

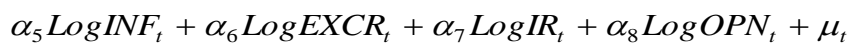

where $\alpha_{0}$ is the intercept term, NOEX is non-oil exports, FD is fiscal deficit (a proxy for fiscal policy), M2 and IR are broad money supply and interest rate respectively (proxies for monetary policy), INST is institutions, 
INF is inflation (a proxy for macroeconomic instability), EXCR is exchange rate, OPN is degree of openness, both of which are control variables and $\mu_{t}$ is a white-noise disturbance term.

The Autoregressive Distributed Lag (ARDL) model of the specification in equation (1) is presented as follows:

$$
\begin{aligned}
& \Delta \log (N O E X)_{t}=\alpha_{0}+\sum_{i=1}^{k} \alpha_{1 i} \Delta \log (N O E X)_{t-i}+\sum_{i=0}^{k} \alpha_{2 i} \log \Delta F D_{t-i}+\sum_{i=0}^{k} \alpha_{3 i} \log \Delta M 2_{t-i}+
\end{aligned}
$$

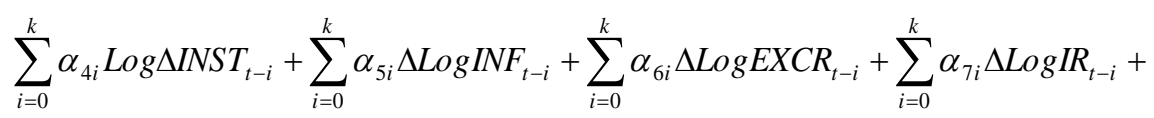

$$
\begin{aligned}
& \sum_{i=0}^{k} \alpha_{8 i} \Delta \log O P N_{t-i}+\mu_{t}
\end{aligned}
$$

where $\Delta$ is the first-difference operator and $k$ the lag length.

Accordingly, the unrestricted error correction model which follows the order of ARDL specification of non-oil export growth for the above ARDL model is presented in equation 3:

$$
\begin{aligned}
& \Delta \log (\operatorname{NOEX})_{t}=\alpha_{0}+\sum_{i=1}^{k} \alpha_{1 i} \Delta \log (\operatorname{NOEX})_{t-i}+\sum_{i=0}^{k} \alpha_{2 i} \Delta \operatorname{LogFD} t_{t-i}+\sum_{i=0}^{k} \alpha_{3 i} \Delta \log M 2_{t-i}+ \\
& \sum_{i=0}^{k} \alpha_{4 i} \Delta{\log I N S T_{t-i}}+\sum_{i=0}^{k} \alpha_{5 i} \Delta \log \operatorname{INF}_{t-i}+\sum_{i=0}^{k} \alpha_{6 i} \Delta{\log E X C R_{t-i}}+\sum_{i=0}^{k} \alpha_{7 i} \Delta{\log I R_{t-i}}_{+}+
\end{aligned}
$$

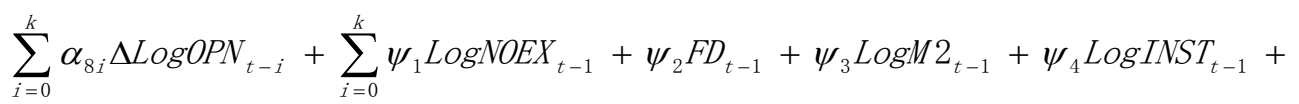

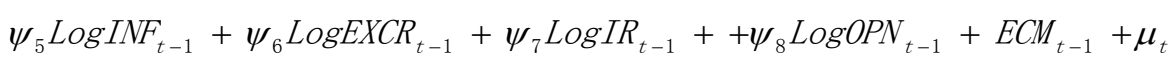

where the parameters $\alpha_{i}: \mathrm{i}=1,2, \ldots 8$ are the short-run dynamic coefficients, while the parameters $\psi_{i}: \mathrm{i}=1,2, \ldots$ 8 function as the long-run multipliers of the underlying ARDL model. The choice of lag length (k) was determined by the Final prediction error (FPE) and Akaike information criterion (AIC), following Liew (2004), who shows that that the AIC and FPE are superior to other criteria in the case of small sample (60 observations and below) for estimating autoregressive lag length, as the criteria maximize the chance of recovering the true lag length, while minimizing the chance of under estimation.

Two steps were followed to test the long-run relationship between the variables. First, the Wald-test was conducted to determine the existence of any long run relationship. This was conducted by imposing restrictions on the estimated long run coefficients. The null and alternative hypotheses are stated as follows:

$\mathrm{H}_{0}: \alpha_{1}=\alpha_{2}=\alpha_{3}=\alpha_{4}=\alpha_{5}=\alpha_{6}=\alpha_{7}=\alpha_{8}=0$ against the alternative hypothesis:

$\mathrm{H}_{1}: \alpha_{1} \neq \alpha_{2} \neq \alpha_{3} \neq \alpha_{4} \neq \alpha_{5} \neq \alpha_{6} \neq \alpha_{7} \neq \alpha_{8} \neq 0$

Thereafter, the long run coefficients of the specified model was estimated, followed by the short run coefficients using the error correction representation of the ARDL specification, in order to establish the speed of adjustment to equilibrium. The standard Granger-type causality tests augmented with a lagged error-correction term were executed.

\section{Results and Discussion}

The results of the tests for stationarity of the variables employed in the study are presented in Table A1 of Appendix A. Panel 1 of Table A1 shows the results of the unit root tests with intercept. For ADF, all the variables are stationary at first difference with the exemption of INST. For PP, all the variables are stationary at first difference with the exemption of INST and FD. For KPSS, the null hypothesis that the variables are stationary in levels is rejected for all variables except INST. All the variables are stationary at first levels with respect to ERS except for INST.

In Panel 2 of Table A1, the results of the unit root tests with intercept and linear trend are presented. For ADF, all the variables except INST are stationary at first difference. For PP, all except INST, OPN and FD are stationary at first difference. For KPSS, the null hypothesis that the variables are stationary is rejected for KPSS for all variables except INST, OPN and EXCR. With respect to ERS, all are stationary at first difference, i.e. all have a unit root in levels. 
It is noteworthy that all five tests of unit roots tend to lead to the same conclusion and are thus consistent. None of the variables is integrated of order 2. The implication of the unit root tests is that, on the whole, the autoregressive distributed lag model employed is appropriate.

The results of the bounds cointegration test are presented in Table A2 of the Appendix. Results in Table A2 suggest that there exists a long-run relationship between non-oil exports, fiscal deficit, broad money supply, interest rate, institutions, inflation, exchange rate, and openness. The computed F-statistic (4.89) is higher than the upper bounds of the critical values at the 10,5 and 1 percent levels respectively.

\subsection{Long-Run Analysis}

The estimated long-run coefficients are shown in Table 2.

Table 2. Long-run estimates

\begin{tabular}{lccc}
\hline Variable & Coefficient & Standard Error & t-values \\
\hline Constant & $2.424076^{*}$ & 0.756797 & 3.203071 \\
NOEX $_{\mathrm{t}-1}$ & $0.545391^{*}$ & 0.101863 & 5.354166 \\
FD & -0.153510 & 0.095355 & -1.609875 \\
M2 & $0.146268^{* *}$ & 0.055408 & 2.639821 \\
INST & $-0.469894^{*}$ & 0.174533 & -2.692291 \\
INF & 0.001487 & 0.001700 & 0.874954 \\
EXCR & $0.513224^{*}$ & 0.100743 & 5.094371 \\
IR & $-0.506590^{*}$ & 0.156067 & -3.245971 \\
OPN & $-0.559329^{*}$ & 0.191552 & -2.919985 \\
\hline Diagnostic Statistics & & & \\
\hline $\mathrm{R}^{2}$ & 0.99 & & \\
Adjusted $\mathrm{R}^{2}$ & 0.99 & & \\
SER & 0.265715 & & \\
F-stat & $579.7360(0.0000)$ & & \\
DW & 2.09 & & \\
JB & $1.333878(0.513277)$ & & \\
BG $\left[\chi^{2}, 1\right]$ & $0.246080(0.6198)$ & & \\
BG $\left[\chi^{2}, 2\right]$ & $1.437599(0.4873)$ & & \\
ARCH $\left(\chi^{2}\right)$ & $47.89860(0.3176)$ & & \\
RESET & $1.756736(0.1926)$ & & \\
\hline
\end{tabular}

Note. ${ }^{*}{ }^{* *}$ and ${ }^{* * *}$ represent $1 \%, 5 \%$ and $10 \%$ level of significance respectively. Chi-square values and number of lags are in square bracket. SER: Standard error of regression; WB: Durbin-Watson stat test for serial correlation; JB: Jarque-Bera test for normality of residuals; BG: Breusch-Godfrey Serial Correlation LM Test; ARCH: Engle's test for conditional heteroskedasticity; RESET: Ramsey's Residual error Specification Test.

Source: Authors' computations.

From Table 2, the coefficient of fiscal deficit is inversely related to non-oil exports and it is not statistically significant, implying that the non-oil sector is not encouraged by government's fiscal actions. In other words, government's spending does not seem to be attuned to the real sector of the economy and specifically in the non-oil sector such as agriculture, manufacturing and solid minerals which have been grossly undermined by the emphasis on crude oil production. Consequently, a $1 \%$ rise in fiscal deficit is associated with $0.15 \%$ reduction in non-oil exports.

Broad money supply is statistically significant at the 5\% level and is positively associated with non-oil exports. Thus a rise in money supply by $1 \%$, on the average, raises non-oil exports by about $0.15 \%$. This is in line with the expectations of theory. As the money supply rises, it is expected that the level of interest rates falls, inducing businesses to access investible funds. A rise in investment raises employment and income, thus improving the level of non-oil output.

The institutional variable is inversely related to non-oil exports and is statistically significant at the $1 \%$ level. The implication of this is that 'constraints on the executive' and by extension the development and dynamics of political institutions and machinery in Nigeria tends to undermine the performance of the economy. Thus poor 
political structures tend to weaken the capacity of the economy to grow. The result is hardly surprising, given the nature and development of political institutions in Nigeria. Institutions of political dimensions such as independent electoral agencies, strong and effective anti-corruption agencies, virile opposition, effective frameworks for political transitions, strong and robust legislative arm of government, independent and effective judiciary and the like, all important stimulants of long-term growth and economic performance are in various degrees of neglect in Nigeria, with the consequence that non-oil performance is impacted negatively.

Inflation is positively related to non-oil imports in the long run, and thus tends to strengthen the view that inflation, especially of the demand side is not unhealthy for macroeconomic performance. The theoretical underpinning is that with demand pull inflation, driven partly by rising population and income levels, there is a transfer of resources from consumers to producers, implying greater accumulation of capital for investment. That long-run positive relationship can thus exist between inflation and non-oil growth is plausible. However it should be noted that the coefficient of inflation is not statistically significant, implying that in the long-run, inflation is not a very important factor explaining the growth of Nigeria's non-oil exports. From the estimated results, a $1 \%$ rise in inflation is associated with a marginal $0.001 \%$ increase in the level of non-oil exports.

The coefficient of exchange rate is statistically significant at the $1 \%$ level and has a positive relationship with non-oil exports. This result suggests that exchange rate depreciation promotes higher export volumes, all things being equal. From the results, a $1 \%$ increase in exchange rate (i.e. depreciation) is associated with $0.51 \%$ increase in the level of non-oil exports. The results are in accordance with theory. Depreciation in the exchange rate generally implies cheaper exports and costlier imports, a situation that is good for an economy in the grip of unemployment and poverty. This is because depreciation tends to discourage imports and encourage exports via its positive impact on a country's international competitiveness. However, it must be stated that in an environment where supporting institutions are weak and inert, and where policies are not geared towards stimulating the real sector of the economy, the use of depreciation as a mechanism for promoting non-oil export growth is not likely to be helpful.

The interest rate coefficient is inversely related to non-oil exports and is statistically significant at the $1 \%$ level. Higher interest rates are not supportive of higher growth in the non-oil sector of the economy. From the empirical results, a $1 \%$ rise in the level of interest is associated with a $0.51 \%$ fall in non-oil exports. In essence, with higher interest rates, the non-oil sector performance is undermined. This is consistent with the prediction of theory. With a rise in interest rate, ceteris paribus, investment capital becomes generally costlier to acquire, so that there is a cut in the level of investment, which affects aggregate non-oil output. The situation can be exacerbated by greater degrees of openness of the economy, which encourages more quantity of goods to be imported even at lower prices than those that obtain locally, leaving the net effect on non-oil exports negative.

The coefficient of openness is negatively related to non-oil exports and is statistically significant at the $1 \%$ level. Consequently, a rise in the degree of openness by $1 \%$ tends to reduce non-oil exports by about $0.56 \%$. In essence, openness is not healthy for Nigeria's non-oil exports. When it is remembered that Nigeria has been a net-importer of goods over the years, and noting that the proportion of total trade which forms part of the computation of openness is not in favour of Nigeria's exports, the result is plausible. With higher volumes of goods as imports and the reverse of imports, it is not in doubt that the openness of the Nigerian economy does not seem to support growth in the country's non-oil exports.

The diagnostic statistics are satisfactory. Variation of about $99 \%$ in non-oil exports is explained by policy, institution and associated variables. The F-statistic and its associated p-value indicate joint statistical significance of all the regressors. The Breusch-Godfrey (BG) statistic shows acceptance of the null hypothesis of no serial autocorrelation at the associated lags. From the results of Durbin-Watson test, the null hypothesis of no serial autocorrelation is rejected. It needs to be stated however the BG test is more appropriate to test for the presence or otherwise of autocorrelation where the lagged dependent variable is a regressor, as is the case with the estimated model. The ARCH test results indicate the precence of homoskedasticity. The regression specification error test result indicates that the long-term non-oil exports function for the Nigerian economy does not suffer specification bias within the period of investigation.

\subsection{Short-Run Analysis}

The short run estimates of the ARDL model are presented in Table 3. 
Table 3. Short-run estimates

\begin{tabular}{|c|c|c|c|}
\hline Variable & Coefficient & Standard Error & t-values \\
\hline Constant & -0.028976 & 0.063629 & -0.455394 \\
\hline$\Delta$ NOEX $_{\mathrm{t}-1}$ & $0.536497^{*}$ & 0.134478 & 3.989470 \\
\hline$\Delta \mathrm{NOEX}_{\mathrm{t}-4}$ & $0.268556^{*}$ & 0.088580 & 3.031804 \\
\hline$\Delta \mathrm{FD}_{\mathrm{t}-1}$ & $-0.244520^{*}$ & 0.054925 & -4.451913 \\
\hline$\Delta \mathrm{M} 2_{\mathrm{t}-1}$ & $0.513853^{* *}$ & 0.246252 & 2.086695 \\
\hline$\Delta \mathrm{INST}$ & $-0.310674^{* *}$ & 0.142074 & -2.186698 \\
\hline$\Delta \mathrm{INST}_{\mathrm{t}-1}$ & $-0.861505^{*}$ & 0.145296 & -5.929298 \\
\hline$\Delta \mathrm{INST}_{\mathrm{t}-2}$ & $-0.487414^{*}$ & 0.159495 & -3.055990 \\
\hline$\Delta \mathrm{INST}_{\mathrm{t}-3}$ & $-0.781480^{*}$ & 0.146689 & -5.327478 \\
\hline$\Delta \mathrm{INF}$ & $-0.003402^{* *}$ & 0.001303 & -2.611621 \\
\hline$\Delta \mathrm{INF}_{\mathrm{t}-2}$ & $-0.009519^{*}$ & 0.001433 & -6.644409 \\
\hline$\Delta \mathrm{EXCR}_{\mathrm{t}-1}$ & $0.442541^{*}$ & 0.124316 & 3.559801 \\
\hline$\Delta \mathrm{EXCR}_{\mathrm{t}-3}$ & $0.732353^{*}$ & 0.143991 & 5.086118 \\
\hline$\Delta \mathrm{IR}_{\mathrm{t}-3}$ & $-0.538351^{* *}$ & 0.204827 & -2.628321 \\
\hline$\Delta \mathrm{OPN}_{\mathrm{t}-1}$ & $-0.312265^{* * *}$ & 0.174134 & -1.793240 \\
\hline$\Delta \mathrm{OPN}_{\mathrm{t}-3}$ & $-0.755079^{*}$ & 0.191363 & -3.945804 \\
\hline $\operatorname{ECM}(-1)$ & $-0.807985^{*}$ & 0.177323 & -4.556581 \\
\hline \multicolumn{4}{|c|}{ Diagnostic Statistics } \\
\hline $\mathrm{R}^{2}$ & 0.89 & & \\
\hline Adjusted $\mathrm{R}^{2}$ & 0.81 & & \\
\hline SER & 0.173899 & & \\
\hline F-stat & $10.23930(0.0000)$ & & \\
\hline DW & 1.92 & & \\
\hline $\mathrm{JB}$ & $1.475911(0.478090)$ & & \\
\hline $\mathrm{BG}\left[\chi^{2}, 1\right]$ & $0.042711(0.8363)$ & & \\
\hline $\mathrm{BG}\left[\chi^{2}, 2\right]$ & $0.085896(0.9580)$ & & \\
\hline $\mathrm{ARCH}\left[\chi^{2}, 1\right]$ & $1.085860(0.2974)$ & & \\
\hline $\mathrm{ARCH}\left[\chi^{2}, 2\right]$ & $1.496686(0.4731)$ & & \\
\hline RESET & $1.962271(0.1634)$ & & \\
\hline
\end{tabular}

Note.,${ }^{* *}$ and ${ }^{* * *}$ represent $1 \%, 5 \%$ and $10 \%$ level of significance respectively. Probability values are in parenthesis. Chi-square values and number of lags are in square bracket. SER: Standard error of regression; WB: Durbin-Watson stat test for serial correlation; JB: Jarque-Bera test for normality of residuals; BG: Breusch-Godfrey Serial Correlation LM Test; ARCH: Engle's test for conditional heteroskedasticity; RESET: Ramsey's Residual error Specification Test.

Source: Authors' computations.

In Table 3, the results of the coefficient of fiscal deficits indicate a statistically significant negative relationship. Deficits are thus non-supportive of non-oil exports in Nigeria. The implication of this is that with public sector inefficiency and a buildup of deficit over time, often financed by sale of government bonds, leading to the crowding out of private investment, the required investment to stimulate non-oil sector growth is absent. With huge interest costs to service debts and the plethora of bottlenecks such as policy summersault and poor budget implementation, it is not of place to expect that past values of deficits will bring less and less to non-oil output, which ultimately impacts the volume of non-oil exports negatively. It must be stressed that Nigeria's fiscal deficits have grown massively over the years to support a large and growing government size. What may be inferred from the estimated result is that the Nigerian experience tends to be supportive of the view that a large and growing government size, which crystallizes into fiscal deficits is not beneficial to non-oil exports, owing largely to the inefficiencies and distortions arising from government interventions. Many empirical studies are in support of this (Folster \& Henrekson, 2001; Anaman, 2004).

Money supply is positively associated with non-oil exports and statistically significant at the 5\% level. Consequently a rise in the supply of money, ceteris paribus, would exert a downward pull on interest rate, and thus promote investment and non-oil exports, in line with economic postulation.

All the current and lagged coefficients of the institutional variable are statistically significant and inversely related to non-oil exports. The implication is that institutions have rather undermined the performance of the 
non-oil sector of the Nigerian economy. The intuition here is that constraints on the executive tend to retard non-oil growth. Of note is that policies as defined and set by the government are a determinant of the economic environment in which economic agents operate.

The coefficients of macroeconomic instability (represented by inflation) are all statistically significant and negatively related to non-oil exports. Consequently, both current and lagged value of inflation tends to be harmful to Nigeria's non-oil export trajectory in the short run. This result is plausible given that during inflationary periods, the value of goods and services produced are eroded, many of which are produced using inputs such as chemicals and tools which are usually imported. With cost push inflation, and an environment of relatively high interest rate, power insufficiency and infrastructural gaps, all of which are growth-inhibiting, the real non-oil sector of the economy is usually the most hit. Within the context of policy initiatives, the Nigerian inflation experience has been largely one that is driven by costs, and this became particularly pervasive from the mid-1980s, when the Structural Adjustment Programme (SAP) was embarked upon. With this came various shades of initiatives such as economic liberalization, privatization, floating exchange rate and the like, one undisguised consequence of which was progressive hikes in prices. Because a large proportion of non-oil export goods in Nigeria are agricultural products, it is to be expected that inflation, ceteris paribus, should encourage higher exports. However, when situated within the context of an environment inundated with a multiplicity of bottlenecks in terms of policy making and implementation, exports are constrained largely by higher prices resulting from higher costs of inputs.

The estimated results indicate that exchange rate is statistically significant and positively related to non-oil exports. This result is not surprising given that when there is an increase in the amount of naira to be given up in exchange for the dollar, it tends to discourage imports. However, it needs to be noted that this may not immediately translate to improvement in non-oil exports. It is not out of place to maintain that depreciation in naira will, ceteris paribus, translate into higher prices of essential commodities due to the preponderance of production inputs which are often imported and which consequently enter into prices. Thus, higher input prices induced by devaluation will tend to reduce the capacity for expansion, leading to a drop in exports. However, there is the possibility that with the passage of time, exports will adjust due to the fall in imports occasioned by relatively higher import commodities. It needs to be emphasized that exchange rate reforms have as its core the stimulation of exports over and above imports in order to improve a country's balance of trade. In the literature, there is considerable argument for and against the use of exchange rates as a panacea to improve performance through exports, making it controversial. For instance the conclusion that can be reached by the proponents of the elasticity approach (e.g. Robinson, 1947; Kreuger, 1983) is that the effect of devaluation on trade balance depends on the elasticity of exports and imports, such that the higher import prices induced by devaluation can stimulate increases in domestic prices of non-traded goods. On the other hand, advocates of the absorption approach maintain that devaluation changes the terms of trade, increases production, switches expenditure from foreign to domestic goods, all of which can improve exports (Johnson, 1967). The coefficients of a change in the lagged value of exchange rate indicate a statistically significant and positive relationship with non-oil exports, suggesting that exports responds positively and adjusts to devaluation with lags. An examination of Nigeria's exchange rate movements over time shows that the amount of naira relative to the dollar has tended to be on the increase. The traditionalist view is that currency depreciation leads to an increase in trade volume through lower export prices. However, in line with the structuralist school, currency depreciation from an initial trade deficit tends to reduce real national income and may even lead to a fall in aggregate demand. Consequently, by lowering export prices, devaluation can take away the benefits by raising import prices, so that should trade remain unchanged, these price changes might offset each other; and for a country where imports exceed exports, as has been the case with Nigeria over the years, real income can fall (Diaz-Alejandro, 1984). It is instructive to note that exchange rate tends to affect imports more than exports owing to the multifarious nature of imports vis-à-vis the mono-cultural nature of exports in Nigeria. This is underscored on the fact that exchange rate depreciation directly affects the prices of tradable goods and indirectly affects the general price level especially if pricing decisions are determined by the cost of imported inputs. It needs to be emphasized that the impact of exchange rate movements on non-oil exports in Nigeria is traceable to a variety of other important factors. Omojimite and Akpokodje (2010) asserted that these factors range from changing trends in foreign trade, changes in institutional setting, and structural shifts in production. For example, the increased dependence on crude oil occasioned severe trade shocks from global oil prices, leading to exchange rate fluctuations between 1978 and 1985 and linked inextricably to fiscal deficits, owing to ambitious development projects embarked upon by government, all of which induced expansionary monetary-fiscal policy. This consequently exerted an upward pressure on inflation and exchange rates (Iyoha \& Oriakhi, 2002; Ogunleye, 2010). 
The interest rate coefficient indicates a negative relationship with non-oil exports and statistically significant at the 5\% level. The postulation of theory is that tight monetary policy through an increase in interest rate should lead to a fall in the demand for money, prices and output while impacting exchange rate positively. Consequently, an increase in interest rate worsens the balance of payments position. This result is of particular interest given interest rate trajectory in Nigeria over the period of study. Specifically, agriculture and manufacturing have been badly hit relative to the oil sector.

The coefficient of openness is negatively statistically significant, implying that the openness of the Nigerian economy has been rather harmful to the improvement of the country's non-oil exports. The results are hardly surprising given that the Nigerian economy has been import-dependent over the years. When it is underscored on non-oil trade, the evidence is that the country has consistently recorded chronic deficits. It is important to stress that the importation of production inputs such as machines, raw materials and chemicals have been on the increase over the years, the direct impact of which is that the country has had to pay more than it received in international non-oil trade.

As expected, the coefficient of the error correction mechanism (ECM) is negative, and is statistically significant at the $1 \%$ level. It indicates that a deviation in non-oil exports from equilibrium is corrected by as much as 81 per cent the following year. Thus, the speed of adjustment is high. In addition, the coefficient of the ECM provides supplementary proof of the existence of a longrun relationship (cointegration) between non-oil exports and the variables employed in the model.

The diagnostic results are adequate. The Adjusted $\mathrm{R}^{2}$, which indicates the overall fit of the estimated model shows that the independent variables employed in the model jointly accounted for 81 percent of the total variation in Nigeria's non-oil export performance. The F-Statistic and its associated probability are indicative of the joint significance of all the variables employed. Moreover, the estimated model satisfies both the Durbin-Watson (DW) and Breusch-Godfrey serial correlation tests (up to 2 lags), as both reject the null hypothesis of serial correlation in the residuals. The model also passes the test of normality, as indicated by JB statistic, which on the basis of the probability of obtaining the value, indicates that the null hypothesis of normally distributed error term cannot be rejected. In addition, the null hypothesis of heteroskedasticity is rejected at all the associated lags. The non-statistically significant F-statistic of the residual error specification test (RESET) is affirmative of a correctly specified model.

\subsection{Stability Tests}

To determine the stability of the short-run coefficients, the cumulative sum of recursive (CUSUM) and cumulative sum of squares of recursive residuals (CUSUMSQ) tests were adopted, and are shown in Figures A1 and $\mathrm{A} 2$ respectively of the Appendix.

From Figures A1 and A2, both the CUSUM and CUSUMSQ plots do not cross the 5\% critical lines, indicating that the estimated coefficients are stable over the entire sample period of investigation. Thus there is parameter constancy in the estimated model, and the results of the regression coefficients are an appropriate guide in the formulation of policy for Nigeria.

\subsection{Causality Tests}

The Granger causality test results between non-oil exports and associated explanatory variables are presented in Table B1 of the Appendix.

The results in Table B1 indicate that fiscal deficits Granger-cause non-oil exports and it is statistically significant at the 5\% level. Similarly, there is unidirectional causality running from non-oil exports to institutions (statistically significant at the $10 \%$ level), from inflation to non-oil exports which is statistically significant at the $5 \%$ level, from exchange rates to non-oil exports which is statistically significant at the $1 \%$ level, from interest rate to non-oil exports (statistically significant at the 10\% level), and from non-oil exports to openness (significant at the $10 \%$ level).

There is no flow of causality from money supply and openness respectively to non-oil exports. Overall, the results tend to indicate that Nigeria's non-oil exports are predictable by fiscal deficits, in addition to exchange and interest rates. It is plausible to maintain that the country's economic performance from the point of view of non-oil exports can be gleamed from prevailing government fiscal stances over the years, the level and movements of interest rates and the overall average exchange rates of the naira.

\section{Conclusion}

The impact of policy and institutions on non-oil exports in Nigeria was investigated in this paper, using datafrom 
secondary sources for the period 1961-2012. The autoregressive distributed lag framework was employed for analysis. A long-run relationship was found between non-oil exports and the associated variables. In both the long and short run, broad money supply and exchange rate were found to be positively associated with and statistically significant determinants of non-oil exports.Both the short and long run results indicate that fiscal deficit, interest rate, 'constraints on the executive' and openness are inversely related to non-oil exports and statistically significant (with the exception of fiscal deficit which is not statistically significant in the long run). Importantly, institutions as measured by 'constraints on the executive' tend to undermine the performance of non-oil exports of the Nigerian economy.The results of the relationship between inflation and non-oil exports are mixed. While it is negatively related to non-oil exports in the short run, results of the short run analysis suggest otherwise. The CUSUM and CUSUMSQ tests indicate that the estimated coefficients are stable over the entire period of study.

Increased money supply and proper exchange rate management are recommended as a means of driving non-oil exports. There is need to reduce fiscal deficit and interest rate. A reduced fiscal deficit can ease the pressure on the market for loanable fund and consequently the crowding out of private investment. Reduced interest rate regime can compliment fiscal deficit reduction and improve the real sector of the economy from the point of view of increased investment.

The benefits of developing political institutions in Nigeria cannot be overemphasized. First, it is instrumental to an equitable and responsible political culture which enthrones a stable macroeconomic environment through proper policy formulation and implementation. In essence, the improvement of non-oil exports and the broader provision of an environment where the citizens can be truly allowed to develop their political space are ensured when political institutions are improved for service delivery. There is need to deepen capacity of political institutions, as a means of improving and sustaining higher non-oil export performance in Nigeria. Consequently, an enhanced political framework is required. Nigeria's non-oil exports respond negatively to executive constraints, the implication being that constraints tend to undermine non-oil exports performance. This is particularly relevant as the country's scorecard on various political institutional indicators has been dismal over the years. The policy implication of the empirical results is that constraints on the executive would tend to undermine exports and that, other measures put in place to improve exports without addressing deep-rooted political inhibitions are not likely to be successful.

From the foregoing, economic policies for Nigeria are not likely to achieve set objectives in an environment that is inundated with a multiplicity of constraints. The success of achieving higher exports can be ensured when constraints are removed at all governmental and executive levels. However, dealing with executive constraints of a bureaucratic nature as endemic in Nigeria requires legal processes, especially in an era of global democratic expectations.

Above all, the openness of the economy needs to be attuned in a manner that promotes domestic production while curtailing consumption imports. Increased local production can in turn impact the level of inflation which may result in the short run and help the country compete favourably with the international community in the long run.

\section{References}

Abolagba, E. O., Onyekwere, N. C., Agbonkpolor, B. N., \& Umar, H. Y. (2010). Determinants of agricultural exports. Kamla-Raj Journal of Human Ecology, 29, 181-184.

Acemoglu, D., Johnson, S., \& Robinson, J. (2002). Reversal of fortune: Geography and institutions in the making of the modern world income distribution. Quarterly Journal of Economics, 117, 1231-1294. http://dx.doi.org/10.1162/003355302320935025

Acemoglu, D., Johnson, S., Robinson, J., \& Thaicharoen, Y. (2003). Institutional causes, macroeconomic symptoms: Volatility, crises and growth. Journal of Monetary Economics, 50, 49-123. http://dx.doi.org/10.1016/S0304-3932(02)00208-8

Adubi, A. A., \& Okunmadewa, F. (1999). Price, exchange rate volatility and Nigeria's agricultural trade flows: A dynamic analysis. AERC Research Paper, p. 87. March

Anaman, K. A. (2004). Determinants of economic growth in Brunei Darussalam. Journal of Asian Economics, 15, 777-796. http://dx.doi.org/10.1016/j.asieco.2004.05.019

Ayres, C. (1962). The theory of economic progress: A study of the fundamental economic development and cultural change. Schocken, New York. 
Bernardina, A. (2004). Price and income elasticities of Russian exports. The European Journal of Comparative Economics, 1, 175-193.

Central Bank of Nigeria. (various issues). Statistical Bulletin. Abuja, Nigeria.

Diaz-Alejandro, C. F. (1984). Exchange rate and terms of trade in the Argentine Republic: 1973-1976. In Syrquin IVI, \& S. Teitel (Eds.), Trade stability, technology and equity in Latin America. New York: Academic Press.

Engle, R. F., \& Granger, C. W. J. (1987). Cointegration and error-correction: Representation, estimation and testing. Econometrica, 55, 251-276. http://dx.doi.org/10.2307/1913236

Fatas, A., \& Mihov, I. (2005). Policy volatility, institutions and economic growth. INSEAD and CEPR Discussion Papers 5388.

Folster, S., \& Henrekson, M. (2001). Growth effects of government expenditure and taxation in rich countries. European Economic Review, 45, 1501-1520. http://dx.doi.org/10.1016/S0014-2921(00)00083-0

Goldstein, J., \& Pevehouse, C. (2008). International relations (8th ed.). New York: Pearson Longman.

Hall, R. E., \& Jones, C. I. (1999). Why do countries produce so much more per worker than others. Quarterly Journal of Economics, 114, 83-116. http://dx.doi.org/10.1162/003355399555954

Iyoha, A. M., \& Oriakhi, D. (2002). Explaining African economic growth performance: The case of Nigeria. Report on Nigerian case study prepared for AERC project on "Explaining African Economic growth performance."

Johansen, S. (1988). Statistical analysis of co-integrating vectors. Journal of Economic Dynamics and Control, 12, 231-254. http://dx.doi.org/10.1016/0165-1889(88)90041-3

Johansen, S. (1996). Likelihood-based inference in cointegrated vector auto-regressive models (2nd ed.). Oxford: Oxford University Press.

Johansen, S., \& Juselius, K. (1990). Maximum likelihood estimation and inference on cointegration-with applications to the demand for money. Oxford Bulletin of Economics and Statistics, 52, 169-210. http://dx.doi.org/10.1111/j.1468-0084.1990.mp52002003.x

Johnson, H. G. (1967). Towards a general theory of the balance of payments. In International trade and economic growth: Studies in pure theory. Cambridge Mass: Harvard University Press.

Knack.S., \& Keefer, P. (1995). Institutions and economic performance: Cross-country tests using alternative $\begin{array}{llllll}\text { institutional measures. Economics and } & \text { Politics, } & \text { 7, 228. }\end{array}$ http://dx.doi.org/10.1111/j.1468-0343.1995.tb00111.x

Krueger, A. O. (1983). Exchange-rate determination. Cambridge: Cambridge University Press.

Lewis, A. (1955). The theory of economic growth. London: George Allen and Unwin.

Liew, V. K. (2004). Which lag length selection criteria should we employ? Economics Bulletin, 3, 1-9.

Masoud, H., \& Rastegari, F. (2008). Analysis of economic-political factors affecting non oil export of Iran. Idosi Publications.

Mauro, P. (1995). Corruption and growth. Quarterly Journal of Economics, 110, 681-712. http://dx.doi.org/10.2307/2946696

McCombie, J. S. L., \& Thirlwall, A. P. (1994). Economic growth and the balance-of-payments constraint. New York: St. Martin's. http://dx.doi.org/10.1007/978-1-349-23121-8

Ogun, O. (1998). Real exchange rate movements and export growth: Nigeria, 1960-1990. African Economic Research Consortium, November.

Ogunleye, E. K. (2010). Exchange rate volatility and foreign direct investment in sub-Saharan Africa: Evidences from Nigeria and South Africa. Retrieved 7 February, 2010 from http://www.resourcespolicy

Omojimite, B. U., \& Akpokodje, G. (2010). The impact of exchange rate reforms on trade performances in Nigeria. Journal of Social Sciences. Retrieved 9 January, 2011 from http://www.krepublishers.com

Oyejide, T. A. (1986). The effects of trade and exchange rate policies on agriculture in Nigeria. IFPRI Research Report No. 55.

Pesaran, M. H., Shin, Y., \& Smith, R. (2001). Bounds testing approaches to the analysis of level relationships. 
Journal of Applied Econometrics, 16, 289-326. http://dx.doi.org/10.1002/jae.616

Phillips, P., \& Hansen, B. (1990). Statistical inference in instrumental variables regression with I(1) process. Review of Economic Studies, 57, 99-125. http://dx.doi.org/10.2307/2297545

Robinson, J. (1947). Essays in the theory of employment. Oxford: Basil Blackwell.

Rodrik, D. (2000). Institutions and high-quality growth: What are they and how to get them. Studies in Comparative International Development, 35, 3-31. http://dx.doi.org/10.1007/BF02699764

Sorsa P. (1999). Algeria-The real exchange rate, export diversification, and trade protection. Policy Development and Review Department, International Monetary Fund. April. http://dx.doi.org/10.5089/9781451846829.001

Tsebelis, G. (2002). Veto players. Princeton University Press. http://dx.doi.org/10.1515/9781400831456

\section{Appendix A}

Table A1. Unit Root Tests

Panel 1: Unit Root Test Results (with intercept)

\begin{tabular}{lcccc}
\hline Variable & ADF & PP & KPSS & ERS \\
\hline NOEX & 0.819332 & 0.791547 & $1.658842^{*}$ & $69.32271^{*}$ \\
FD & -1.971243 & $-3.856005^{* *}$ & $0.669898^{* *}$ & $16.43439^{*}$ \\
M2 & 0.814772 & 1.260250 & $1.812231^{*}$ & $1175.774^{*}$ \\
INST & -1.657543 & -2.029813 & $0.899317^{*}$ & $4.533947^{*}$ \\
INF & 4.108302 & 4.592538 & $1.801288^{*}$ & $240.5515^{*}$ \\
EXCR & -0.033218 & 0.242027 & $1.675361^{*}$ & $70.25529^{*}$ \\
IR & -1.290115 & -1.229544 & $1.22623^{*}$ & $21.12124^{*}$ \\
OPN & -1.779806 & -2.189072 & $1.780003^{*}$ & $7.502530^{*}$ \\
$\Delta$ NOEX & $-4.037764^{*}$ & $-7.103045^{*}$ & 0.319962 & 0.644249 \\
$\Delta$ FD & $-6.106895^{*}$ & -7.629692 & 0.176456 & 0.537546 \\
$\Delta$ M2 & $-3.756030^{*}$ & $-4.029261^{*}$ & 0.267452 & 1.358451 \\
$\Delta$ INST & $-4.255584^{*}$ & $-8.568329^{*}$ & 0.052089 & 0.797668 \\
$\Delta$ INF & $-3.031793^{* *}$ & $-5.898143^{*}$ & 1.413082 & 2.249957 \\
$\Delta$ EXCR & $-3.098359^{* *}$ & $-5.595031^{*}$ & 0.290622 & 1.557656 \\
$\Delta$ IR & $-3.429939^{* *}$ & $-8.248183^{*}$ & 0.119470 & 2.017405 \\
$\Delta$ OPN & $-6.118923^{*}$ & -10.60134 & 0.036788 & 1.255854 \\
\hline
\end{tabular}

Panel 2: Unit Root Test Results (with intercept and a linear trend)

\begin{tabular}{lcccc}
\hline \multicolumn{1}{c}{ Variable } & ADF & PP & KPSS & ERS \\
\hline NOEX & -1.739956 & -1.850448 & $0.393821^{*}$ & $25.32691^{*}$ \\
FD & -2.639050 & $-4.728844^{*}$ & $0.138230^{* * *}$ & $14.68728^{*}$ \\
M2 & -2.780060 & -2.924795 & $0.201184^{* *}$ & $22.12298^{*}$ \\
INST & -2.669345 & -3.106702 & $0.139593^{* * *}$ & $5.542794^{*}$ \\
INF & 1.672322 & 1.352194 & $0.597011^{*}$ & $268.4844^{*}$ \\
EXCR & -2.037412 & -1.939192 & 0.216000 & $29.45019^{*}$ \\
IR & -0.945539 & -1.717822 & $0.261654^{*}$ & $25.28278^{*}$ \\
OPN & -2.720609 & $-3.861680^{* *}$ & 0.105809 & $7.162641^{*}$ \\
$\Delta$ NOEX & $-4.272718^{*}$ & $-7.378402^{*}$ & 0.054224 & 1.262648 \\
$\Delta$ FD & -6.023890 & -7.528269 & 0.105848 & 1.137010 \\
$\Delta$ M2 & $-3.923819^{* *}$ & $-4.105415^{* *}$ & 0.076549 & 2.080943 \\
$\Delta \mathrm{INST}$ & $-4.227516^{*}$ & $-8.499684^{*}$ & 0.038154 & 2.893507 \\
$\Delta \mathrm{INF}$ & $-4.763468^{*}$ & $-8.365050^{*}$ & 0.190238 & 4.545537 \\
$\Delta \mathrm{EXCR}$ & -3.107910 & $-5.648628^{*}$ & 0.166258 & 4.984541 \\
$\Delta \mathrm{IR}$ & $-3.390581^{* * *}$ & $-8.171280^{*}$ & 0.110132 & 6.321089 \\
$\Delta$ OPN & $-6.064025^{*}$ & -10.49356 & 0.036593 & 3.916891 \\
\hline
\end{tabular}

Note. $* * *$ and $* * *$ denote rejection of the null hypothesis at $1 \%, 5 \%$ and $10 \%$ level of significance respectively. The null hypothesis is that the variable (in series) is non-stationary for ADF, PP and ERS. For KPSS, the null hypothesis is that the variable is stationary. Maximum lag used is 2 .

Source: Authors' computations. 
Table A2. Bounds test for cointegration

\begin{tabular}{ccc}
\hline & Computed F-statistic:4.89 $(\mathrm{K}=8)$ \\
\hline Level of significance & Lower Bound statistic & Upper Bound statistic \\
\hline 0.01 & 2.79 & 4.10 \\
0.05 & 2.22 & 3.39 \\
0.10 & 1.95 & 3.06 \\
\hline
\end{tabular}

Source: Pesaran et al. (2001), Table CI (iii), Case 111: Unrestricted intercept and no trend. $\mathrm{K}$ is the number of regressors in the ARDL model.

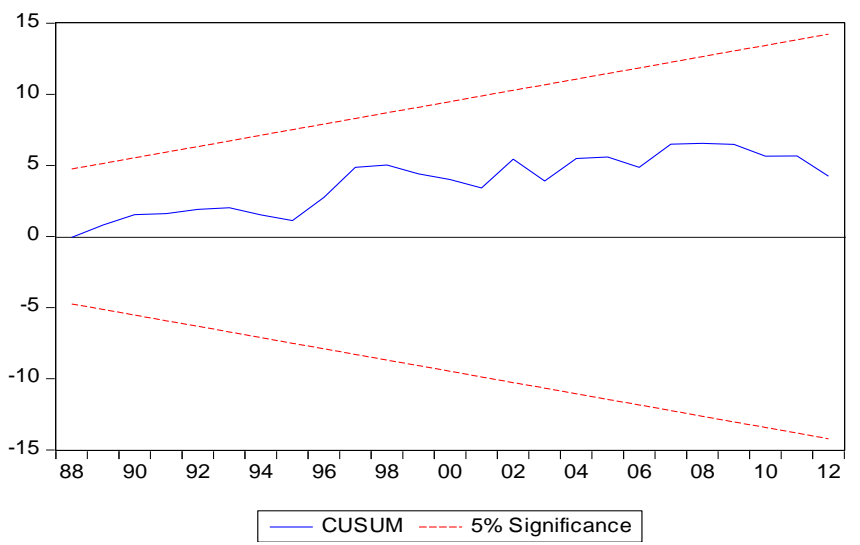

Figure A1. Plot of cumulative sum of recursive residuals

Source: Authors' computations.

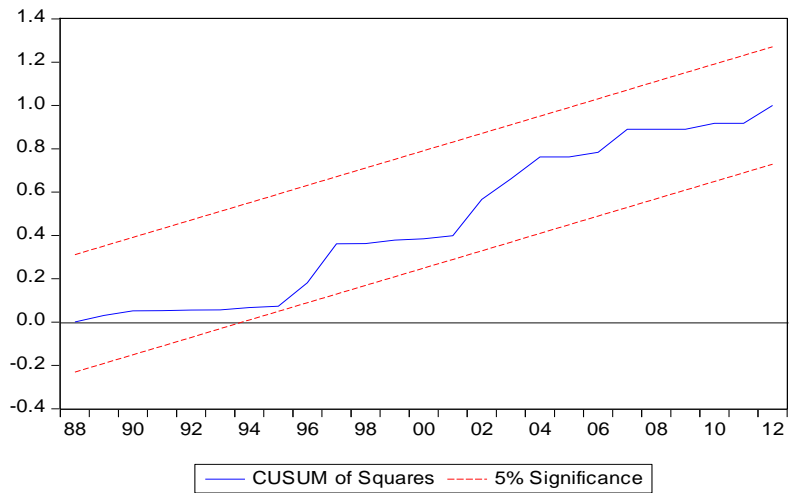

Figure A2. Plot of cumulative sum of recursive residuals

Source: Authors' computations.

\section{Appendix B}

Table B1. Causality test results

\begin{tabular}{lccc}
\hline Null Hypothesis & F-Statistic & Result & Decision \\
\hline FD $\rightarrow$ NOEX & $3.43443^{* *}$ & Reject & \\
NOEX $\rightarrow$ FD & 0.76979 & Accept & Unidirectional \\
\hline M2 $\rightarrow$ NOEX & 1.25416 & Accept & \\
NOEX $\rightarrow$ M2 & 0.69798 & Accept & Independent \\
\hline INST $\rightarrow$ NOEX & 0.76604 & Accept & \\
NOEX $\rightarrow$ INST & $2.44540^{* * *}$ & Reject & Unidirectional \\
\hline INF $\rightarrow$ NOEX & $3.46877^{* *}$ & Reject & \\
NOEX $\rightarrow$ INF & 0.76710 & Accept & Unidirectional \\
\hline EXCR $\rightarrow$ NOEX & $4.36666^{*}$ & Reject & \\
NOEX $\rightarrow$ EXCR & 0.62782 & Accept & Unidirectional \\
\hline
\end{tabular}




\begin{tabular}{lccc}
\hline IR $\nrightarrow$ NOEX & $2.40012^{* * *}$ & Reject & \\
NOEX $\rightarrow$ IR & 1.50483 & Accept & Unidirectional \\
\hline OPN $\nrightarrow$ NOEX & 1.30179 & Accept & \\
NOEX $\nrightarrow$ OPN & $2.06675^{* * *}$ & Reject & Unidirectional \\
\hline
\end{tabular}

Note. $\rightarrow$ denotes "does not Granger-cause".,${ }^{* *}$ and ${ }^{* * *}$ represent $1 \%, 5 \%$ and $10 \%$ level of significance respectively. Lag length $=4$, based on AIC.

Source: Authors' computations.

\section{Copyrights}

Copyright for this article is retained by the author(s), with first publication rights granted to the journal.

This is an open-access article distributed under the terms and conditions of the Creative Commons Attribution license (http://creativecommons.org/licenses/by/3.0/). 